\title{
Performance Modeling of the Weather Impact on a Utility-Scale PV Power Plant in a Tropical Region
}

\author{
Ajith Gopi, ${ }^{1,2,3}$ K. Sudhakar $\mathbb{D}^{3,4,5}$ Ngui Wai Keng, ${ }^{1}$ Ananthu R. Krishnan, ${ }^{6}$ \\ and S. Shanmuga Priya ${ }^{7}{ }^{7}$ \\ ${ }^{1}$ College of Engineering, Universiti Malaysia Pahang, 26300, Gambang, Kuantan, Pahang, Malaysia \\ ${ }^{2}$ Agency for New and Renewable Energy Research and Technology (ANERT), Thiruvananthapuram, Kerala, India \\ ${ }^{3}$ Centre for Automotive Engineering, Universiti Malaysia Pahang, 26600 Pekan, Pahang, Malaysia \\ ${ }^{4}$ Faculty of Mechanical and Automotive Engineering Technology, Universiti Malaysia Pahang, 26600 Pekan, Pahang, Malaysia \\ ${ }^{5}$ Energy Centre, Maulana Azad National Institute of Technology, Bhopal, India \\ ${ }^{6}$ IEEE, Kerala Section, Thiruvananthapuram, 695001 Kerala, India \\ ${ }^{7}$ Department of Chemical Engineering, Manipal Institute of Technology, Manipal Academy of Higher Education, Manipal, \\ Karnataka, India
}

Correspondence should be addressed to K. Sudhakar; sudhakar@ump.edu.my and S. Shanmuga Priya; shan.priya@manipal.edu Received 25 January 2021; Revised 31 May 2021; Accepted 15 June 2021; Published 28 June 2021

Academic Editor: Umapada Pal

Copyright (c) 2021 Ajith Gopi et al. This is an open access article distributed under the Creative Commons Attribution License, which permits unrestricted use, distribution, and reproduction in any medium, provided the original work is properly cited.

\begin{abstract}
Solar photovoltaics and the associated applications are now considered the most promising technologies for a sustainable future. The performance of the PV power plants is not studied in detail with respect to the influence of various weather parameters like rain, relative humidity, and atmospheric pressure on energy generation. The objective of this research work is to analyze and model the weather impact of a utility-scale PV power plant in a tropical region. The methodology involves the detailed analysis of the PV plant performance for various weather seasons and modeling the energy generation based on important weather parameters obtained from a Solar Radiation Resource Assessment (SRRA) station installed at the PV power plant location itself. Solar generation and its performance are affected during the rainy seasons, and it turns out to be a typical phenomenon in the humid tropical region. A regression model of solar generation for all the weather seasons is generated based on different weather parameters.
\end{abstract}

\section{Introduction}

Solar PV has a greater role in the global energy transition for meeting the challenges of climate change. The Paris Agreement demands the global nations to limit the global temperature rise to $1.5^{\circ} \mathrm{C}$. Energy-related carbon emission has to be reduced by around 3.5\% per year to 2050 to address this challenge. The demand for solar PV is increasing across the world, and it becomes the most competitive option for electricity generation in many numbers of countries. Solar PV is expected to become the cheapest source of energy by 2050 in the regions where solar radiation is abundant [1]. A total cumulative solar PV capacity of $627 \mathrm{GW}$ was installed up to 2019. The interest in solar PV capacity addition resulted in the addition of at least $1 \mathrm{GW}$ capacity in more than 29 countries up to 2019. The major share in gridconnected renewables is from utility-scale solar power plants and also from the rooftop sector. The cost of solar PV continued to decline mainly due to the reduction in the price of PV modules [2]. According to the International Renewable Energy Agency, solar generation is increased by $28 \%$ from the previous year based on the data available from the sources [3]. Ground-mounted utility-scale solar PV projects had a major share of $70-72 \%$ in the global installed capacity. Utility-scale PV plants continue to be the major contributor to PV capacity addition in the world [4]. The performance of the solar PV power plant is influenced by various weather parameters like solar irradiation, temperature, wind speed, 
TABLE 1: Summary of the relevant performance studies conducted in a different climate region.

\begin{tabular}{|c|c|c|c|c|c|c|}
\hline Reference & Country/site & Capacity & Climate & $\begin{array}{c}\text { Performance } \\
\text { ratio }(\mathrm{PR})\end{array}$ & $\begin{array}{l}\text { Method of data } \\
\text { collection }\end{array}$ & $\begin{array}{c}\text { Module } \\
\text { technology }\end{array}$ \\
\hline [14] & Sivaganga, India & $5 \mathrm{MW}$ & $\begin{array}{l}\text { Tropical and hot } \\
\text { climate }\end{array}$ & $80 \%$ & SCADA & $\begin{array}{c}\text { Thin } \\
\text { amorphous }\end{array}$ \\
\hline$[15]$ & Ramagundam, India & $10 \mathrm{MW}$ & $\begin{array}{l}\text { Tropical and hot } \\
\text { climate }\end{array}$ & $86.12 \%$ & SCADA & Poly C-Si \\
\hline$[16]$ & Tiruchirappalli, India & $20 \mathrm{kWp}$ & $\begin{array}{l}\text { Tropical and hot } \\
\text { climate }\end{array}$ & $82 \%$ & - & Poly C-Si \\
\hline$[17]$ & Agra (city), Uttar Pradesh, India & $40 \mathrm{kWp}$ & Semiarid climate & $63 \%$ & - & Mono C-Si \\
\hline$[18]$ & Visakhapatnam, India & $1 \mathrm{MWp}$ & $\begin{array}{l}\text { Tropical and hot } \\
\text { climate }\end{array}$ & $88 \%$ & - & Poly C-Si \\
\hline [19] & Dhaka, Bangladesh & $80 \mathrm{kWp}$ & & $66 \%$ & - & Mono C-Si \\
\hline$[20]$ & $\begin{array}{l}\text { Cochin International Airport, } \\
\text { Kochi, India }\end{array}$ & $12 \mathrm{MWp}$ & $\begin{array}{l}\text { Tropical and hot } \\
\text { climate }\end{array}$ & $86.56 \%$ & SCADA & Poly C-Si \\
\hline [21] & $\begin{array}{c}\text { Raja Bhoj International Airport, } \\
\text { Bhopal, India }\end{array}$ & $2 \mathrm{MWp}$ & $\begin{array}{l}\text { Tropical and hot } \\
\text { climate }\end{array}$ & $85.54 \%$ & - & Poly C-Si \\
\hline$[22]$ & Roorkee, India & $\begin{array}{l}1816 \\
\mathrm{kWp}\end{array}$ & $\mathrm{N} / \mathrm{A}$ & $63.68 \%$ & - & Poly C-Si \\
\hline$[23]$ & Morocco & $5 \mathrm{kWp}$ & $\mathrm{N} / \mathrm{A}$ & $79 \%$ & - & Poly C-Si \\
\hline$[24]$ & Ghana, 2013 & $2.5 \mathrm{MW}$ & Tropical country & $70.4 \%$ & $\begin{array}{l}\text { Data logging } \\
\text { system }\end{array}$ & Poly C-Si \\
\hline [25] & Algeria & $2.5 \mathrm{kWp}$ & Hot dry climate & $73.85 \%$ & - & Mono C-Si \\
\hline$[26]$ & Djibouti & $\begin{array}{l}302.4 \\
\mathrm{kWp}\end{array}$ & $\begin{array}{l}\text { Tropical desert } \\
\text { maritime climate }\end{array}$ & $84 \%$ & - & Poly C-Si \\
\hline [27] & Nouakchott, Mauritania & $15 \mathrm{MWp}$ & Arid climate & 63.59 to $73.56 \%$ & Data logger & Thin film \\
\hline [28] & Nouakchott, Mauritania & $\begin{array}{l}954,809 \\
\mathrm{kWp}\end{array}$ & Arid climate & $61 \%$ to $71 \%$ & $\begin{array}{l}\text { Data monitoring } \\
\text { system }\end{array}$ & Thin film \\
\hline
\end{tabular}

rain, humidity, and atmospheric pressure. The output of the PV modules depends on the solar radiation falling on the surface. The operation and maintenance of solar PV plants play a vital role in improving the performance of PV power plants. The operation and maintenance of a PV plant are extremely important for its sustainability [5].

\section{Literature Review: Weather-Related Studies Conducted in Solar Power Plants}

The performance of the solar PV power plant is influenced by various weather parameters like solar irradiation, temperature, wind speed, rain, humidity, and atmospheric pressure. The output of the PV modules depends on the solar radiation falling on the surface [6]. Parretta et al. evaluated the performance of various PV technologies in the tropical region. Wijeratne et al. described the various software tools which deal with feasibility, operation, and maintenance cost, the performance of the PV plant, and the irradiation calculation [7]. Killinger et al. described the power generation between differently oriented PV systems based on a measurement from a reference system [8]. Martín-Martínez et al. studied the influence of ambient temperature and wind speed on the performance of six large-scale PV power plants in Spain [9]. Mussard and Amara discussed the performance analysis of various PV module technologies in an arid climatic condition [10]. Dabou et al. evaluated the power output on various climatic conditions in South Algeria [11]. Pina et al. analyzed the solar PV plant installed in Latvia utilizing a regression model [12]. Vasel and Iakovidis discussed the effect of wind direction on the performance of a utility-scale PV plant [13]. The relevant performance studies conducted in different climate regions are summarized in Table 1.

Based on Table 1, the performance ratio of the PV plant was found to vary between $61 \%$ and $88 \%$. There is a large variation in the performance of the plant among different climates.

Most of the utility-scale power plants are installed with an embedded data monitoring system which includes a cellbased or thermopile-based pyranometer for solar radiation measurement. Most of the studies were conducted by utilizing the data from conventional data monitoring systems embedded with the solar power plant project when it is constructed by the developer. Sensors for measuring the ambient temperature, wind speed, and module temperature are also incorporated in most of the embedded data monitoring systems. All these studies have limitations since the data is completely dependent upon the measuring instruments of various qualities. Also, there is a chance that the instruments may not be calibrated as per the standards. However, these measuring instruments if not calibrated regularly may end up with erroneous measurement which will lead to wrong performance conclusions of the solar power plants. All the above studies were conducted based on the average monthly 


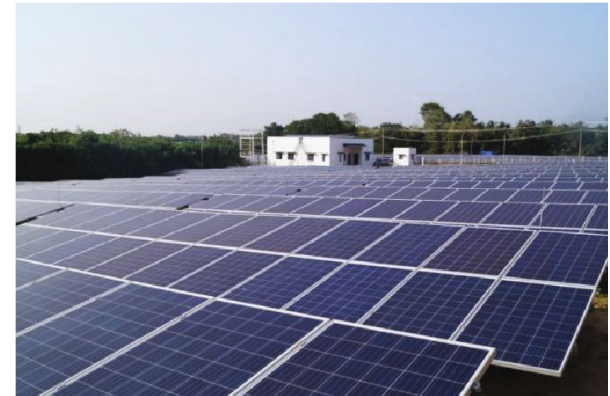

Figure 1: Site view of ANERT 2 MWp Kuzhalmannam solar PV power plant.

data and not based upon an hourly average or daily average. Hence, the results and the conclusion in the referred studies have the limitation of detailed hourly/daily analysis.

A comprehensive analysis of the performance modeling of PV plant generation and the influence of weather parameters like the effect of humidity, atmospheric pressure, and rain are not reported by researchers in detail. Considering the gaps in studies as found in the literature, this research work is carried out with the most accurate and reliable data from a Solar Radiation Resource Assessment (SRRA) station installed as part of the National Solar Resource Assessment Programme conducted in India.

In this paper, the influence of weather parameters like solar irradiation, air temperature, rain, wind speed, atmospheric pressure, and dew point on the performance of PV plants is studied in detail using a very sophisticated Solar Radiation Research Assessment (SRRA) station.

The objectives of this research work are as follows:

(1) To analyze the weather impact of a utility-scale PV power plant in a humid tropical region utilizing SRRA data

(2) To develop a mathematical regression model for the solar generation in different weather seasons utilizing all weather parameters

(3) To establish a probability distribution model to predict the solar generation on varying irradiance

\section{Methodology}

3.1. Site Details and Conditions. The PV plant is situated in the southern state of Kerala in South India. This research is conducted based on the recent SRRA data of 2019. The 2 MW solar power plant selected for the study is located in a humid tropical region where the rain has got a more considerable influence on the weather pattern of the area [29]. The 2 MW solar power plant is situated at Kuzhalmannam in the Palakkad District of Kerala, South India. A site view of the 2 MWp PV power plant is given in Figure 1. The site is situated $17 \mathrm{~km}$ away from Palakkad Town. The plant was commissioned in December 2016. The geographical coordinates of the PV plant are 10.717 latitude and 76.613 longitude. The PV plant is solely owned by the Agency for New and Renew- able Energy Research and Technology (ANERT), which is the State Nodal Agency of Renewable Energy under the Power Department of the Kerala Government.

Thomas and Prasannakumar described that the state of Kerala is experiencing tropical humid climatic conditions with two monsoon periods with more than three months of heavy rainy seasons [29]. Ananthakrishnan and Soman had described a comprehensive estimation of the rain in Kerala [30]. According to Hunt and Menon, the monsoon is spread over 6 months in Kerala with an average of $300 \mathrm{~mm}$ rain [31].

3.2. Data Collection. A typical SRRA station installation is shown in Figure 2. This SRRA station is installed as part of a separate Solar Radiation Resource Assessment Programme in different parts of the country and installed on the same premises of the $2 \mathrm{MW}$ solar PV plant which turned out to be a novel arrangement for the measurement of different weather parameters utilizing state-of-the-art measuring instruments. The methodology involves accurate weather data collection from a Solar Radiation Resource Assessment (SRRA) station. This SRRA station is used as a primary data collection source for the study. The SRRA station is operational since November 2018, and the big data is streaming since then from the SRRA station and is being stored in the central server. This data is continuously monitored in the central server. This data at a one-minute interval is collected through the above measuring sensors and transferred in realtime from the SRRA station. The most recent year of 2019 is taken for analyzing the influence of weather along with the generation data of the PV power plant which is available from the traditional embedded data monitoring system.

Table 2 gives the summary of the measuring instruments in the SRRA station which are used for measuring the weather parameters at the site of the PV power plant.

The following data is available from the SRRA station:

(i) Direct normal irradiation (DNI)

(ii) Global horizontal irradiation (GHI)

(iii) Diffused horizontal irradiation (DHI)

(iv) Wind speed and direction

(v) Relative humidity

(vi) Rain

(vii) Atmospheric pressure

(viii) Solar elevation

(ix) Solar azimuth

(x) Dew point

The SRRA station provides the data of global horizontal irradiation through a pyranometer. Global tilted irradiation is calculated for determining various performance parameters like performance ratio and module temperature. The data logger and modem at the SRRA station combined with GPRS will accomplish the task of data collection and monitoring. 

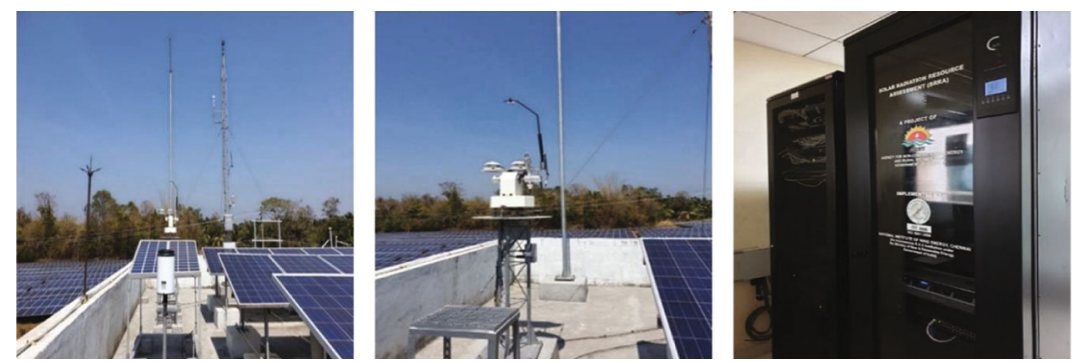

FIgURE 2: Dedicated SRRA station at the site and central data server for the real-time collection of the data.

TABLE 2: Summary of measuring instruments in an SRRA station.

\begin{tabular}{|c|c|c|c|}
\hline Sl no. & Instrument & Manufacturer & Parameter \\
\hline \multicolumn{4}{|c|}{ A. Solar measuring instruments } \\
\hline 1 & Pyranometer & $\begin{array}{l}\text { Phase I: Eppley, USA } \\
\text { Phase II: Hukseflux, NL }\end{array}$ & Global radiation $\left(\mathrm{W} / \mathrm{m}^{2}\right)$-instantaneous, average \\
\hline 2 & Shaded pyranometer & - do- & Diffuse radiation $\left(\mathrm{W} / \mathrm{m}^{2}\right)$-instantaneous, average \\
\hline 3 & Pyrheliometer & - do- & Direct irradiance $\left(\mathrm{W} / \mathrm{m}^{2}\right)$-instantaneous, average \\
\hline 4 & Solar tracker & Geonica, Spain & Mounted with shaded pyranometers and pyrheliometer \\
\hline \multicolumn{4}{|c|}{ B. Meteorological measuring instruments } \\
\hline 5 & Ultrasonic wind sensor & R. M. Young, USA & $\begin{array}{l}\text { Wind speed and wind direction-standard deviation, } \\
\text { maximum, and average }\end{array}$ \\
\hline 6 & Rain gauge & - do- & Rain accumulation \\
\hline 7 & Pressure sensor & - do- & Atmospheric pressure \\
\hline 8 & Temperature \& relative humidity sensor & -do- & Temperature and humidity-average, maximum, and minimum \\
\hline \multicolumn{4}{|c|}{ C. General instruments } \\
\hline 9 & GPS & Garmin, USA & To synchronize sun tracker with sun movement \\
\hline 10 & Data logger \& modem & Geonica, Spain & Collecting data from sensors \\
\hline 11 & GPRS & Garmin, USA & To transfer data through mobile SIM cards \\
\hline 12 & Solar PV panel & Moser Baer, India & For charging battery for powering the station \\
\hline 13 & External battery & Exide, India & For electrical storage \\
\hline
\end{tabular}

3.3. Determination of Global Tilted Irradiation and Module Temperature from SRRA Data. The methodology of this research work includes the following:

(i) Primary data collection from the SRRA station

(ii) Determination of global tilted radiation and module temperature from SRRA data

(iii) Modeling the PV generation utilizing Minitab software

(iv) Analysis of the variation of PV plant performance

(v) Comparison of the seasonal performance of the plant

Kalogirou has consolidated various mathematical equations used for the determination of global tilted irradiation and module temperature [32]. The equations are given below.

3.3.1. Estimation of Global Tilted Irradiation. Global tilted irradiation $\left(G_{\mathrm{Bt}}\right)$ or the beam radiation on a tilted surface is calculated by multiplying global horizontal irradiation (GB) and beam radiation tilt factor (RB). Global horizontal irradiation is the sum of the beam (direct) and diffuse radiation and is also known as "global radiation."

$$
G_{\mathrm{Bt}}=G_{\mathrm{B}} \times \mathrm{R}_{\mathrm{B}} \text {. }
$$

The beam radiation tilt factor $(\mathrm{RB})$ is given by

$$
R_{\mathrm{B}}=\frac{\sin (L-\beta) \sin (\delta)+\cos (\mathrm{L}-\beta) \cos (\delta) \cos (h)}{\sin (L) \sin (\delta)+\cos (L) \cos (\delta) \cos (h)} .
$$

The declination angle $(\delta)$ is defined as the angle between the lines joining the centers of the sun and the earth, which also determines the direction of the direct rays coming from the sun and their projection on the equatorial plane and is given by

$$
\delta=23.45 \sin \left[\frac{360}{365}(284+N)\right]
$$


The value of $N$ is the date number which ranges from 1 to 365 .

The zenith angle is the angle between the sun's rays and the line perpendicular to a horizontal plane, and the hour angle is the angular displacement of the sun from the local meridian because of the earth's rotation around its own axis [33].

The hour angle $(h)$ is given by

$$
\cos (\omega s)=-\tan (L) \tan (\delta) .
$$

The latitude $(N)$ is also an important factor determining the hour angle as given above.

Estimation of module temperature is given by

$$
\begin{gathered}
T_{\mathrm{c}}=30+0.0175\left(G_{\mathrm{t}}-300\right)+1.14\left(T_{\mathrm{a}}-25\right), \\
\text { Plant efficiency }=\frac{E_{\text {grid }} * 100}{G_{\mathrm{Bt}} * A_{\text {mod }}} .
\end{gathered}
$$

3.4. Data Analysis and Modeling. Weather in the state is broadly divided into four seasons including two monsoons and summer and winter seasons. The performance of the solar PV power plant is assessed for the above four seasons by utilizing the SRRA data collected for the entire year of 2019. Northeast monsoon, southwest monsoon, and summer and winter seasons are separately taken for analyzing the PV plant behavior based on the variation of different weather parameters. The following analysis is done for the 2019 data collected from the SRRA station:

(1) Detailed analysis for a selected month in a season

(2) Yearly data analysis

The various months that represent the typical characteristics of the season are selected for the regression modeling and arrive at the energy generation model equations.

\subsection{Modeling the PV Generation with Weather Parameters.} Minitab is the statistical tool used for this analysis and for arriving at regression model equations from big data. Minitab is a statistical package developed at Pennsylvania State University, USA. It offers various computations in the field of big data analytics. Here, the weather parameters are selected as variables, and the generation is made as a response to various seasons. The outcome of this methodology is the development of a mathematical model for the $2 \mathrm{MWp}$ PV power plant based on various weather parameters. Once the model is created, the generation can be theoretically calculated from the mathematical model. The important weather parameters selected for regression modeling are given in Table 3.

Minitab is also used for fitting the probability distribution plot for a typical generation $(\mathrm{kWh})$ in a day against the representative average daily solar generation $\left(G_{\mathrm{POA}}\right)$ of the year.
TABLE 3: Weather parameters for regression modeling.

\begin{tabular}{lcc}
\hline Parameter & Notations & Remarks \\
\hline Global tilted irradiation & $G_{\mathrm{POA}}$ & $\mathrm{kWh} / \mathrm{m}^{2}$ \\
Wind speed & $\mathrm{WS}$ & $\mathrm{m} / \mathrm{s}$ \\
Air temperature & $T$ & ${ }^{\circ} \mathrm{C}$ \\
Relative humidity & $\mathrm{RH}$ & $\%$ \\
Atmospheric pressure & $P_{\mathrm{ATM}}$ & $\mathrm{Mb}$ \\
Rain & $R$ & $\mathrm{~mm}$ \\
\hline
\end{tabular}

\section{Results and Discussion}

The energy generation profile for different seasons is discussed in the following section. The plant performance results are summarized in Table 4 for arriving at conclusions.

4.1. Seasonal Plant Performance. The classification of seasons is as follows:

(i) Southwest monsoon (June to September)

(ii) Northeast monsoon (October to November)

(iii) Summer (February to May)

(iv) Winter (December to January)

The year 2019 was faced with heavy rain in Kerala, particularly in Palakkad District where the PV plant is located. Tropical humid regions are characterised by rainy seasons, and there will be impact on the PR in these regions due to rain. Month-wise generation, global tilted generation, peak sun hours, PR, wind speed, air temperature, relative humidity, atmospheric pressure, and rain are summarized in Table 4.

It is observed that the performance ratio (PR) of the plant was reasonable during the summer season (Feb-71.67, March-71.72, April-69.75, and May-72.69), obviously due to higher energy generation. The advantage of colder temperature improves the $\mathrm{PR}$ of the plant further during the rainy months of June (75.95) and July (74.09) as compared to the summer season though the overall generation was lower. The highest PR of the plant was observed during September (79.50) owing to the lesser solar radiation. The lowest sun peak hours have been observed as 4.41, 4.04, 3.48, and 4.18 during June, July, August, and September of 2019, respectively, which indicate the reduction in solar insolation during the rainy season. This directly influences the performance of the plant as well.

4.2. Effect of Temperature on Generation. Eight representative days were chosen for different seasons to study the effect of temperature on generation and are presented in Table 5 . Among the eight days, selected for the study, the lowest average ambient temperature was recorded during January obviously due to the winter season. The daily energy generation for the winter days is higher than that for other days chosen for the analysis. The combined effect of optimum temperature and sunshine duration contributed to the higher 
TABLE 4: Summary of monthly average weather parameters.

\begin{tabular}{|c|c|c|c|c|c|c|c|c|c|}
\hline Month & $\begin{array}{l}\text { Generation } \\
(\mathrm{MWh})\end{array}$ & $\begin{array}{l}\text { Monthly tilted } \\
\text { irradiation }\left(\mathrm{kWh} / \mathrm{m}^{2}\right)\end{array}$ & $\begin{array}{l}\text { Peak sun hours per day } \\
\text { during the month }\end{array}$ & PR & $\begin{array}{l}\text { Wind } \\
\text { speed } \\
(\mathrm{m} / \mathrm{s})\end{array}$ & $\begin{array}{c}\text { Air } \\
\text { temp } \\
\left({ }^{\circ} \mathrm{C}\right)\end{array}$ & $\begin{array}{l}\text { Rel. } \\
\text { humidity }\end{array}$ & $\begin{array}{c}\text { Atm. } \\
\text { pressure } \\
(\mathrm{mb})\end{array}$ & $\begin{array}{l}\text { Rain } \\
(\mathrm{mm})\end{array}$ \\
\hline Jan & 267.262 & 190.80 & 6.15 & 69.93 & 3.01 & 26.88 & 68.89 & 1010.96 & 7.8 \\
\hline Feb & 260.593 & 181.53 & 5.86 & 71.67 & 2.35 & 28.53 & 59.52 & 1013.18 & 0.0 \\
\hline Mar & 295.842 & 205.95 & 6.64 & 71.72 & 2.14 & 29.90 & 63.69 & 1010.61 & 2.0 \\
\hline Apr & 258.129 & 184.77 & 5.96 & 69.75 & 2.25 & 30.42 & 68.15 & 1006.45 & 70.7 \\
\hline May & 252.834 & 173.65 & 5.60 & 72.69 & 2.98 & 30.16 & 70.28 & 1006.09 & 37.5 \\
\hline Jun & 207.927 & 136.68 & 4.41 & 75.95 & 2.76 & 27.87 & 81.51 & 1003.14 & 208.0 \\
\hline Jul & 186.007 & 125.34 & 4.04 & 74.09 & 2.56 & 26.25 & 86.37 & 1004.85 & 270.9 \\
\hline Aug & 142.496 & 107.98 & 3.48 & 65.88 & 2.63 & 25.51 & 89.24 & 1005.71 & 571.6 \\
\hline Sept & 206.299 & 129.55 & 4.18 & 79.50 & 2.25 & 26.57 & 86.34 & 1008.90 & 154.8 \\
\hline Oct & 211.321 & 168.87 & 5.45 & 62.47 & 1.76 & 26.66 & 83.30 & 1006.89 & 337.3 \\
\hline Nov & 209.165 & 185.72 & 5.99 & 56.23 & 2.17 & 27.53 & 76.21 & 1010.44 & 80.2 \\
\hline Dec & 211.726 & 169.06 & 5.45 & 62.53 & 3.01 & 26.88 & 68.89 & 1010.96 & 7.8 \\
\hline
\end{tabular}

TABLE 5: PR and generation variation for various selected days with an average temperature.

\begin{tabular}{lccccc}
\hline Date & Average ambient temperature $\left({ }^{\circ} \mathrm{C}\right)$ & Average module temperature $\left({ }^{\circ} \mathrm{C}\right)$ & Daily generation $(\mathrm{kWh})$ & PR $(\%)$ & Days \\
\hline $22-01-19$ & 24.33 & 36.14 & 9865 & 73.36 & Winter \\
$21-08-19$ & 25.97 & 30.05 & 6718 & 77.67 & Southwest monsoon \\
$26-10-19$ & 27.67 & 38.41 & 8772 & 60.84 & Northeast monsoon \\
$14-04-19$ & 31.99 & 44.26 & 8960 & 70.55 & Summer \\
$20-03-19$ & 30.08 & 40.64 & 8277 & 73.82 & Spring equinox \\
$23-09-19$ & 26.84 & 35.66 & 7259 & 65.98 & Fall equinox \\
$21-06-19$ & 26.08 & 31.77 & 5840 & 84.97 & Summer solstice \\
$22-12-19$ & 26.90 & 36.83 & 8247 & 66.14 & Winter solstice \\
\hline
\end{tabular}

generation which clearly shows that the winter seasons are also favorable for energy generation in tropical humid regions. The summer solstice in the tropical region falls in the southwest monsoon season, and hence, lesser generation was observed due to the cloudy and rainy conditions prevailing in the regions. This emphasizes the influence of rain in keeping the ambient temperature lower when compared to the winter months. The air temperature and module temperature show a continuous correlation throughout the seasons. On a typical summer day, the module temperature can reach above $44^{\circ} \mathrm{C}$ and the module temperature shows a comparatively lower level in rainy months as a general tendency in tropical regions. The module temperature follows the air temperature almost constantly throughout the summer seasons which is a common trend in tropical regions.

4.3. Effect of Irradiance on Generation. The eight representative days were chosen for different seasons to study the effect of irradiance on energy generation as illustrated in Table 6. The highest global tilted irradiance has been observed on winter days, and correspondingly higher energy generation happened. Out of 8 days, 4 days achieved more than 8000 $\mathrm{kWh}$ generation which shows the correlation between higher global tilted irradiance and generation. It has been observed that the highest average global tilted irradiations happened during both summer and winter seasons. It is found that both summer and winter days provide the best solar generation among the selected days. The highest global tilted irradiance was observed mostly in summer days except for three days in monsoon. This indicates the importance of summer in tropical regions in achieving higher performance as it is evident from the higher generation values during the summer season.

Hence, it can be concluded that the typical Kerala humid climate supports good generation in the first six months of a year and dips into the lesser generation in monsoon months until it regains the status in the final months of the year.

4.4. Modeling of Solar Generation in Different Weather Seasons. The data from the SRRA weather monitoring station is analyzed for the year 2019, and that has been used to develop a regression model for the entire four weather seasons for a $2 \mathrm{MWp} \mathrm{PV}$ power plant installed in a tropical region. The modeling output is calculated for the typical one day of the selected season as per the model equation below, and then, that value has to be multiplied by the number of days in that season to get the total generation. The weather parameters considered for the study are global tilted irradiation, wind speed, air temperature, relative humidity, atmospheric pressure, and the rain of the site. Here, the solar generation is derived from the selected weather parameters 
TABLE 6: Generation and PR for the days with the average irradiance.

\begin{tabular}{lccccc}
\hline Date & $\begin{array}{c}\text { Global horizontal irradiation } \\
\left(\mathrm{kW} / \mathrm{m}^{2} / \text { day }\right)\end{array}$ & $\begin{array}{c}\text { Global titled irradiance } \\
\left(\mathrm{kWh} / \mathrm{m}^{2} / \text { day }\right)\end{array}$ & Generation $(\mathrm{kWh})$ & Performance ratio $(\%)$ & Days \\
\hline $22-01-19$ & 6.08 & 6.70 & 9865 & 73.36 & Winter \\
$21-08-19$ & 4.43 & 4.31 & 6718 & 77.67 & Southwest monsoon \\
$26-10-19$ & 6.04 & 7.19 & 8772 & 60.84 & Northeast monsoon \\
$14-04-19$ & 6.44 & 6.33 & 8960 & 70.55 & Summer \\
$20-03-19$ & 5.48 & 5.59 & 8277 & 73.82 & Spring equinox \\
$23-09-19$ & 5.37 & 5.49 & 5259 & 65.98 & Fall equinox \\
$21-06-19$ & 3.68 & 3.43 & 5840 & 84.97 & Summer solstice \\
$22-12-19$ & 5.56 & 6.22 & 8247 & 66.14 & Winter solstice \\
\hline
\end{tabular}

TABLE 7: Model testing and validation using 2020 measured data.

\begin{tabular}{|c|c|c|c|c|c|c|c|c|c|}
\hline Year & $\begin{array}{c}\text { Global tilted } \\
\text { irradiance } \\
\left(\mathrm{kWh} / \mathrm{m}^{2}\right)\end{array}$ & $\begin{array}{l}\text { Wind speed } \\
\qquad(\mathrm{m} / \mathrm{s})\end{array}$ & $\begin{array}{l}\text { Air temp } \\
\quad\left({ }^{\circ} \mathrm{C}\right)\end{array}$ & Rel. hum. & $\begin{array}{l}\text { Atm. pressure } \\
(\mathrm{mb})\end{array}$ & $\begin{array}{l}\text { Rain } \\
(\mathrm{mm})\end{array}$ & $\begin{array}{l}\text { Actual generation } \\
\qquad(\mathrm{kWh})\end{array}$ & $\begin{array}{l}\text { Predicted with } \\
\text { the AGS model }\end{array}$ & $\begin{array}{c}\text { Variation } \\
(\%)\end{array}$ \\
\hline $2020(\mathrm{SW})$ & 4.5 & 2.46 & 26.76 & 83.58 & 1003.354 & 154 & 6010 & 6492.33 & 7.29 \\
\hline $2020(S)$ & 7.21 & 2.53 & 28.25 & 57.04 & 1011.88 & 0 & 9455.8 & 10478.92 & 9.76 \\
\hline $2020(\mathrm{~W})$ & 5.8 & 2.44 & 27.34 & 62.90 & 1011.92 & 0.40 & 8697.96 & 9947.81 & 12.56 \\
\hline $2020(\mathrm{NE})$ & \multicolumn{9}{|c|}{ Not tested due to lack of SRRA data for NE monsoon } \\
\hline
\end{tabular}

above. The mathematical model equations (developed by Ajith Gopi, Sudhakar, and Co hereafter named as the AGS model) for typical days of different weather seasons, arriving at utilizing the regression modeling, are listed below:

Southwest monsoon:

$$
\begin{aligned}
E= & 2422+1402.9 G_{\mathrm{POA}}+157 \mathrm{WS}-89 T_{\mathrm{a}} \\
& -7.2 \mathrm{RH}+0.8 P_{\mathrm{ATM}}-2.91 R .
\end{aligned}
$$

Northeast monsoon:

$$
\begin{aligned}
E= & -58186+1480 G_{\mathrm{POA}}+709 \mathrm{WS}+248 T_{\mathrm{a}} \\
& +56.0 \mathrm{RH}+42.9 P_{\mathrm{ATM}}-3.6 R .
\end{aligned}
$$

Summer:

$$
\begin{aligned}
E= & -22790+1259 G_{\mathrm{POA}}+57 \mathrm{WS}+9 T_{\mathrm{a}} \\
& -24.8 \mathrm{RH}+24.9 P_{\mathrm{ATM}}-579 R .
\end{aligned}
$$

Winter:

$$
\begin{aligned}
E= & 147222+1759 G_{\mathrm{POA}}-1567 \mathrm{WS}+202 T_{\mathrm{a}} \\
& -64.6 \mathrm{RH}-145 P_{\mathrm{ATM}}+4069 R .
\end{aligned}
$$

The above models are tested utilizing the 2020 SRRA data, and the results are checked and compared with the actual generation data as given in Table 7 .

The above AGS model can be used to predict energy generation of a 2 MWp PV plant for a typical day in each season based on the important weather parameters in a tropical region as discussed above. The model has been tested and

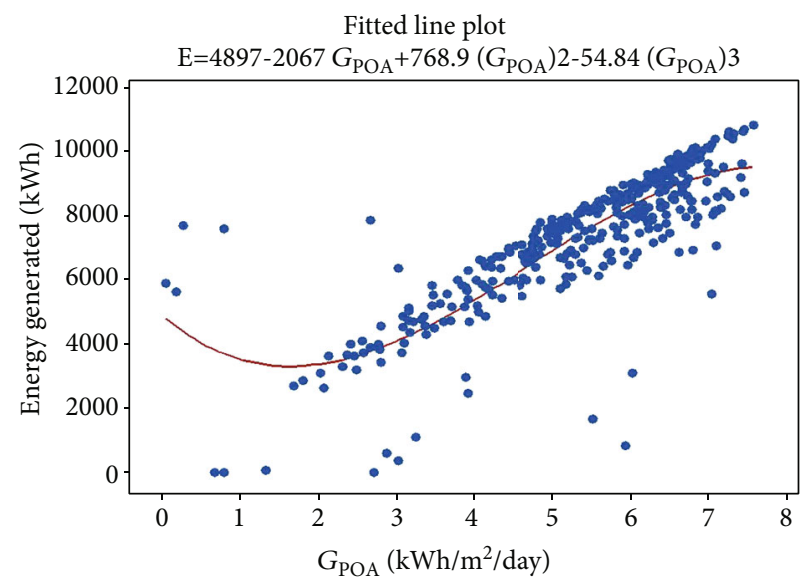

FIgURE 3: Probability distribution model fitted for the $2 \mathrm{MW}$ PV plant.

validated utilizing the 2020 year's measured data. The percentage average variation in the prediction of energy generation using the model is within the acceptable limits (9.87\%). The novelty of this work is that this model brings important weather parameters like wind speed, air temperature, relative humidity, atmospheric pressure, and rain into this model which was not previously taken up in any research work along with seasonal solar power PV plant generation.

4.5. Probability Distribution Model. The data set for the average daily generation $(\mathrm{kWh})$ is plotted against global tilted irradiance as a scatter plot, and a line curve is fitted for the best value as given in Figure 3. The cubic model is arrived at by utilizing the Minitab statistical tool. The scatter plot is 
TABLE 8: Validation of the probability distribution model using 2020 measured data.

\begin{tabular}{lccccc}
\hline Description & $\begin{array}{c}\text { Annual } G_{\mathrm{POA}} \\
\left(\mathrm{kWh} / \mathrm{m}^{2}\right)\end{array}$ & $\begin{array}{c}\text { Annual average } \\
G_{\mathrm{POA}} \text { per day }\end{array}$ & $\begin{array}{c}\text { Actual generation } \\
(\mathrm{kWh})\end{array}$ & $\begin{array}{c}\text { Prediction by } \\
\text { model }(\mathrm{MWh})\end{array}$ & $\begin{array}{c}\text { Percentage of } \\
\text { variation }(\%)\end{array}$ \\
\hline 2018 & 2011.60 & 5.51 & 2701.46 & 2803.05 & -3.76 \\
2020 & 1916.25 & 5.25 & 2704.18 & 2668.56 & 1.31 \\
PVsyst & 2011.70 & 5.51 & 3034.30 (simulated) & 2803.19 & 7.61 \\
\hline
\end{tabular}

accomplished as a probability distribution as per the cubic model equation given below.

$E=4897-2067 G_{\mathrm{POA}}+768.9\left(G_{\mathrm{POA}}\right)^{2}-54.84\left(G_{\mathrm{POA}}\right)^{3}$.

This probability distribution predicts the values for generation in a day on varying irradiance which when multiplied by 365 days will predict the annual generation.

The validation of the probability distribution model is tested using the measured data of 2018 and 2020, and the model is also compared with the PVsyst simulated generation, and the details are summarized in Table 8 . The percentage variation of predicted generation by the probability model in the years of 2018 and 2020 is within the acceptable limits with the actual generation.

This simple model predicts the average daily generation of a 2 MWp PV power plant installed in a tropical region for a complete year with a single parameter of global tilted irradiation in the equation. This model helps for a quick prediction of solar generation PV power plant sites in a tropical region. Predictive maintenance, remote sensing, and solar forecasting will help in monitoring the solar power plant performance.

\section{Conclusion}

This research work studied the influence of important weather parameters on the performance of a utility-scale power plant installed in a humid tropical region in the state of Kerala, a southern state of India. Unlike conventional data collection, big data collected from the Solar Radiation Resource Assessment (SRRA) station is used in this research work for accurate estimation. In addition to the usual weather parameters like ambient temperature, global tilted irradiance, and wind speed, other influential parameters like rain, atmospheric pressure, and humidity are also analyzed and modeled for the major weather seasons of the region. The following are the major outcomes of the study.

(i) Solar generation and its performance are affected during the rainy seasons, and it turns out to be a typical phenomenon in humid tropical regions. It is also understood that the prevailing wind during the monsoon periods does not make much influence on the performance of the PV power plant

(ii) The generation of the PV plant in a tropical region strictly follows the irradiance pattern. Global horizontal irradiation and global tilted irradiation are in analogy providing comparatively higher values compared to monsoon months (iii) It is observed that higher generation happens during the period of lower atmospheric pressure in tropical regions

(iv) Higher generation and reasonable $\mathrm{PR}$ are the highlights of summer seasons. The solar generation and performance characteristics of the winter season are almost the same as those of the summer season in tropical regions since all the performance parameters are observed to be similar. The plant performed well during the summer and winter seasons when compared with the monsoon seasons

(v) The monsoon rain has an influence on the ambient temperature of the region which lowers the module temperature. As a general trend, module temperature follows the ambient temperature throughout the seasons

(vi) The $2 \mathrm{MWp}$ solar PV plant has got comparatively higher PR during rainy seasons due to the advantage of colder temperature during rainy seasons

(vii) The lowest sun peak hours of 4.41, 4.04, 3.48, and 4.18 were observed during June, July, August, and September of 2019, respectively, which hints the lower values of solar insolation during the monsoon months

(viii) The PV power plant has an annual generation of 2709.601 MWh for the year 2019 with an annual irradiance of $1959.9 \mathrm{kWh} / \mathrm{m}^{2}$

(ix) A solar generation model, hereafter named as the AGS model, which predicts the generation for the weather seasons has been developed for a 2 MWp PV plant in a tropical region utilizing regression modeling in Minitab software utilizing important weather parameters like global tilted irradiation, wind speed, air temperature, relative humidity, atmospheric pressure, and the rain of the site

(x) The optimum generation in a typical day for a 2 MWp PV plant in a tropical region utilizing generation and global tilted irradiation is obtained based on the probability distribution model: $E=4897-$ $2067 G_{\mathrm{POA}}+768.9\left(G_{\mathrm{POA}}\right)^{2}-54.84\left(G_{\mathrm{POA}}\right)^{3}$

This research work will aid future studies on performance analysis of PV plants in other geographical regions with different climatic conditions. 


\section{Nomenclature}

$G_{\mathrm{Bt}}: \quad$ Beam radiation on a tilted surface (global tilted irradiation) $\left(\mathrm{W} / \mathrm{m}^{2}\right)$

$G_{\mathrm{B}}: \quad$ Beam radiation on a horizontal plane (global horizontal irradiation) $\left(\mathrm{W} / \mathrm{m}^{2}\right)$

$R_{\mathrm{B}}: \quad$ Beam radiation tilt factor

$L: \quad$ Latitude $\left({ }^{\circ}\right)$

$\beta: \quad$ Tilt angle for PV module $\left({ }^{\circ}\right)$

$\delta: \quad$ Declination angle $\left({ }^{\circ}\right)$

$h$ : $\quad$ Hour angle $\left({ }^{\circ}\right)$

$N$ : $\quad$ Date number in a year, value ranges from 1 to 365

$G_{\mathrm{t}}: \quad$ Global tilted irradiance $\left(\mathrm{kWh} / \mathrm{m}^{2}\right)$

$T_{\mathrm{a}}$ : $\quad$ Ambient air temperature $\left({ }^{\circ} \mathrm{C}\right)$

$G_{\mathrm{POA}}:$ Tilted irradiance $\left(\mathrm{kWh} / \mathrm{m}^{2}\right)$

WS: Wind speed $(\mathrm{m} / \mathrm{s})$

$T: \quad$ Air temperature $\left({ }^{\circ} \mathrm{C}\right)$

RH: Relative humidity (\%)

$P_{\text {ATM}}:$ Atmospheric pressure $(\mathrm{mb})$

$R: \quad$ Rain $(\mathrm{mm})$

$E_{\text {Grid }}: \quad$ AC energy injected to the grid (kWh)

$A_{\text {mod }}$ : Area of the PV module $\left(\mathrm{m}^{2}\right)$

PR: Performance ratio.

\section{Data Availability}

All the performance data used to support the findings of this study are included within the article.

\section{Disclosure}

The authors acknowledge that the data involved in this study, information, and uncertainties in results may contain assumptions, inaccuracies, or errors. So the authors of this manuscript expressly exclude the liability for any such inaccuracies or errors to the fullest extent permitted by law. The opinions or facts or insights and discussions in this document are solely of the authors. It does not necessarily reflect the policy and standpoint of any organization directly or indirectly. Hence, the authors are not responsible for any consequences thereof with the use of information presented in this work.

\section{Conflicts of Interest}

The authors declare that they have no conflicts of interest.

\section{Acknowledgments}

The authors acknowledge the Agency for New and Renewable Energy Research and Technology (ANERT), which is the Kerala State Renewable Nodal Agency under the Department of Power in Government of Kerala, in India, for providing the data for this research work. The authors also acknowledge the National Institute of Wind Energy (NIWE), Chennai, India, for the information provided regarding the SRRA station. The support provided by Universiti Malaysia Pahang (http://www.ump.edu.my) through PGRS210349 and Mr. Sreenath Sukumaran, Ph.D. scholar, UMP, and former master student of MANIT-Bhopal, India, is greatly acknowledged. The second author is greatly indebted to the Board of Management, Maulana Azad National Institute of Technology (MANIT), Bhopal, India, for providing longterm unpaid leave to carry out teaching and research activities at Universiti Malaysia Pahang.

\section{References}

[1] I. International and R. Energy, Future of Deployment, investment technology, grid integration and socio-economic aspects, International Renewable Energy Agency, Abu Dhabi, 2018.

[2] R. E. N. Members, Renewables 2020 global status report 2020, REN21.2020, REN21 Secretariat, Paris, 2020.

[3] I. Renewable and E. Agency, Renewable Energy Statistics 2020, International Renewable Energy Agency, Abu Dhabi, 2020.

[4] F. S. Power, Mobilising Investments in Emerging Markets, International Renewable Energy Agency, Abu Dhabi, 2019.

[5] L. Hernández-callejo, S. Gallardo-saavedra, and V. Alonsogómez, "A review of photovoltaic systems: design, operation and maintenance," Solar Energy, vol. 188, pp. 426-440, 2019.

[6] A. Parretta, A. Sarno, and L. R. M. Vicari, "Effects of solar irradiation conditions on the outdoor performance of photovoltaic modules," Optics Communications, vol. 153, no. 1-3, pp. 153-163, 1998.

[7] W. M. P. U. Wijeratne, R. J. Yang, E. Too, and R. Wakefield, "Design and development of distributed solar PV systems: do the current tools work?," Sustainable Cities and Society, vol. 45, pp. 553-578, 2019.

[8] S. Killinger, F. Braam, B. Müller, B. Wille-Haussmann, and R. McKenna, "Projection of power generation between differently-oriented PV systems," Solar Energy, vol. 136, pp. 153-165, 2016.

[9] S. Martín-Martínez, M. Cañas-Carretón, A. Honrubia-Escribano, and E. Gómez-Lázaro, "Performance evaluation of large solar photovoltaic power plants in Spain," Energy Conversion and Management, vol. 183, pp. 515-528, 2019.

[10] M. Mussard and M. Amara, "Performance of solar photovoltaic modules under arid climatic conditions: a review," Solar Energy, vol. 174, pp. 409-421, 2018.

[11] R. Dabou, F. Bouchafaa, A. H. Arab et al., "Monitoring and performance analysis of grid connected photovoltaic under different climatic conditions in south Algeria," Energy Conversion and Management, vol. 130, pp. 200-206, 2016.

[12] A. Pina, P. Ferrão, J. Fournier, B. Lacarrière, O. Le Corre, and A. I. Andri, "First solar power plant in Latvia. Analysis of operational data," Energy Procedia, vol. 147, pp. 162-165, 2018.

[13] A. Vasel and F. Iakovidis, "The effect of wind direction on the performance of solar PV plants," Energy Conversion and Management, vol. 153, pp. 455-461, 2017.

[14] S. Sundaram and J. S. C. Babu, "Performance evaluation and validation of $5 \mathrm{MW}_{\mathrm{p}}$ grid connected solar photovoltaic plant in South India," Energy Conversion and Management, vol. 100, no. 2015, pp. 429-439, 2015.

[15] B. Shiva Kumar and K. Sudhakar, "Performance evaluation of $10 \mathrm{MW}$ grid connected solar photovoltaic power plant in India," Energy Reports, vol. 1, pp. 184-192, 2015.

[16] K. A. Kumar, K. Sundareswaran, and P. R. Venkateswaran, "Performance study on a grid connected $20 \mathrm{~kW}_{\mathrm{p}}$ solar photovoltaic installation in an industry in Tiruchirappalli (India)," 
Energy for Sustainable Development, vol. 23, pp. 294-304, 2014.

[17] K. P. Satsangi, D. B. Das, G. S. S. Babu, and A. K. Saxena, "Energy for sustainable development performance analysis of grid interactive solar photovoltaic plant in India," Energy for Sustainable Development, vol. 47, pp. 9-16, 2018.

[18] S. Thotakura, S. Chandan Kondamudi, J. F. Xavier et al., "Operational performance of megawatt-scale grid integrated rooftop solar PV system in tropical wet and dry climates of India," Case Studies in Thermal Engineering, vol. 18, article 100602, 2020.

[19] F. Touati, N. A. Chowdhury, K. Benhmed et al., "Long-term performance analysis and power prediction of $\mathrm{PV}$ technology in the State of Qatar," Renewable Energy, vol. 113, pp. 952$965,2017$.

[20] S. Sukumaran and K. Sudhakar, "Fully solar powered airport: a case study of Cochin International Airport," Journal of Air Transport Management, vol. 62, pp. 176-188, 2017.

[21] S. Sukumaran and K. Sudhakar, "Fully solar powered Raja Bhoj International Airport: a feasibility study," Resource-Efficient Technologies, vol. 3, no. 3, pp. 309-316, 2017.

[22] K. Sangram, S. Pundir, N. Varshney, and G. K. Singh, "Comparative study of performance of grid connected solar photovoltaic power system in IIT Roorkee campus," International Jounal of Innoative Research in Science and Engineering, vol. 2, pp. 319-328, 2016.

[23] K. Attari, A. Elyaakoubi, and A. Asselman, "Performance analysis and investigation of a grid-connected photovoltaic installation in Morocco," Energy Reports, vol. 2, pp. 261266, 2016.

[24] L. D. Mensah, J. O. Yamoah, and M. S. Adaramola, "Performance evaluation of a utility-scale grid-tied solar photovoltaic (PV) installation in Ghana," Energy for Sustainable Development, vol. 48, pp. 82-87, 2019.

[25] A. Necaibia, A. Bouraiou, A. Ziane et al., "Analytical assessment of the outdoor performance and efficiency of grid-tied photovoltaic system under hot dry climate in the south of Algeria," Energy Conversion and Management, vol. 171, pp. 778-786, 2018.

[26] D. H. Daher, L. Gaillard, M. Amara, and C. Ménézo, "Impact of tropical desert maritime climate on the performance of a PV grid-connected power plant," Renewable Energy, vol. 125, pp. 729-737, 2018.

[27] C. E. B. Elhadj Sidi, M. L. Ndiaye, M. El Bah, A. Mbodji, A. Ndiaye, and P. A. Ndiaye, "Performance analysis of the first large-scale $\left(15 \mathrm{MW}_{\mathrm{p}}\right)$ grid-connected photovoltaic plant in Mauritania," Energy Conversion and Management, vol. 119, pp. 411-421, 2016.

[28] M. el Hacen Jed, R. Ihaddadene, N. Ihaddadene, C. E. L. B. Elhadji Sidi, and M. el Bah, "Performance analysis of 954,809 kWp PV array of Sheikh Zayed solar power plant (Nouakchott, Mauritania)," Reinforced Plastics, vol. 32, pp. 45-54, 2020.

[29] J. Thomas and V. Prasannakumar, "Temporal analysis of rainfall (1871-2012) and drought characteristics over a tropical monsoon-dominated State (Kerala) of India," Journal of Hydrology, vol. 534, pp. 266-280, 2016.

[30] R. Ananthakrishnan, "The onset of the south west monsoon over Kerala: 1901-1980,” J. Climate, vol. 8, pp. 283-296, 1988.
[31] K. M. R. Hunt and A. Menon, "The 2018 Kerala floods: a climate change perspective," Climate Dynamics, vol. 54, no. 3-4, pp. 2433-2446, 2020.

[32] S. Kalogirou, Solar Energy Engineering, Academic Press, Amsterdam, 2014.

[33] T. Arvind and T. Shyam, Handbook of Solar Energy, 2016th ed, Springer, Singapore, 2016. 